\title{
From Customs to Fashion: Ideologies, Trends, Social Hierarchies
}

\author{
Giovanna Motta \\ Department of Communication and Social Research, Sapienza Università di Roma, Italy
}

Copyright $\subset 2018$ by authors, all rights reserved. Authors agree that this article remains permanently open access under the terms of the Creative Commons Attribution License 4.0 International License

\begin{abstract}
Over the course of history what are the clothes that, in the societies of the Old Regime, differentiate individuals from each other? What styles and colors choose the hegemonic classes to represent and mark the status differences between them, the emerging classes and the common people? What are the signs and symbols that the sources testify as a political, ethical, aesthetic language? This essay tries to answer these and other questions, an essay conducted on the red thread of change in European countries, political, economic, social change that marks the rhythm through FASHION showing how this represents in a real and symbolic way the role of the dominant classes in power. In the course of history, clothing is transformed according to the new ideas that are affirmed and the different perception of which individuals are aware, so the representation of the self - social and individual - becomes an exclusive or additional language, confirming its expressive validity and the content necessary to decline human typologies, to express them, and even to impose them. Fashion contains history and society, art and harmony of forms, religious principles and moral rules, past present, continuity and discontinuity, in short, the life of human beings of yesterday and today, perhaps even of tomorrow.
\end{abstract}

Keywords Fashion and Social Classes, Celebrations, Games, Porcelain

\section{Introduction and Methodology}

History is like a long chain where the rings are linked to each other and in the "longue durée" course each event is a consequence of the previous set-up and will be the cause of what will happen later. Over time, in addition to the exact sciences also within the social sciences the questions advanced by the researchers change in order to give new answers to the societies of yesterday and today. When, during the Twentieth century, the first avant-gardes scholars achieve the overcoming of political, diplomatic, military history - which until then had been the center of the attention of researchers - it reveals the richness of the interdisciplinary research that conjugates economic, social, anthropological history, and it is capable of tackling new issues, accessing new documentary sources, opening new frontiers to research. The themes are numerous, but the research path outlined by the great Braudel prevails, which is divided into three essential points - model, structure, duration - through which he analyzes the production systems, the identity elements, the collective mentality (1981-1982). As a person without memories suffering from the lack of memory of his family history, in the same way collective societies need to rebuild their past to recognize themselves in a common origin, essential for their cohesion. Language, religion, material civilization are all signs that define identity, based on specific characters of national history "built" on common events that link the past to the present. History thus becomes necessary again, it loses its so to speak cultural function, and takes on a much more important role, that of gathering around populations troubled by the processes of globalization to which they try to resist with the affirmation of their own national identity based on their past (which of course can also cause highly negative consequences such as reemerging nationalisms). But it is already a history expanded in its potential thanks to other social sciences, which increases its possibilities of analysis embracing in an organic "whole” ideal processes and behaviors, individual and social values, production relationships, religious options. Subsequently it can support the power or, on the contrary, offer a political alternative to it for the creation of new proposals in harmony with a more innovative social conscience [1]. It is a narrative that includes the history of ruling classes and subaltern classes, the short and long-term history, the history of the world and the history of men, in short, manages to decline indefinitely, articulating differences, expectations, revolutions, moments of crisis and social advancements [2]. In this way the analysis was able to introduce new protagonists that allowed to deal with 
previously ignored themes - such as family and kinship relationships, gender history and the role of women, the age of marriages and the index of birth, sexuality, the articulation of social classes between dominant and emerging classes, health and illness, collective mentality This allowed scholars to approach the thousand stories of ordinary people who gave birth to a new way of doing research by constructing new scenarios and new paradigms, "open" on what around the seventies of the twentieth century was called micro-history, able to put in evidence apparently minor events that nevertheless allowed to distinguish factors of change, motivations, objectives, different from those of history tout court, hence the evolution of European societies and of new social models related to sociology and anthropology. The past, subsequently, is not only the distant memory of yesterday, but also the identity base of today, so its elaboration is important and influences the origin for the union of social groups and their ability to imagine tomorrow. Scientific research, cultural commitment, political militancy contribute to creating a self-awareness in the peoples and a planning of the future that, together with the factors of development, lead to modernization, an indispensable premise for change. Therefore, history from this point of view is manifold and indicates numerous directions crossing times, places, territories that indicate new events and bring out previously neglected themes (for example the defense of minorities). In the historiographic panorama, therefore, a method was established that I would define "democratic" that de-structured the boundary of history and opened it to other social sciences, acquired visibility and became widespread and shared knowledge. "Once liberated, historical research had no more boundaries, could navigate almost everywhere, penetrate society, analyze the canons of the collective mentality and the material conditions of existence, becoming social, economic and anthropological history" [3]. The interest for the latter is evident in the second half of the last century but re-emerges continuously when confronted with systemic crises in post-modern societies - which destabilize the dynamics of economies and politics - defined by Bauman [4], using an inspired expression, "liquid" caused by the chaos created by current realities due to the cancellation of the previous context without yet having established another one, a society characterized by a "disorientation" (as he calls it), a confusion caused by the processes of globalization that seem to swallow the differences and erase every truth previously considered absolute. But, as it has been said so far, the past influences the culture of the present, it is above all through the dynamics of the social classes and thanks to the testimony of their material civilization that it is possible to reconnect the threads of history to post-modern reality. Starting from the societies of the Ancien Régime, one can observe how the background is represented by the court where power intrigues are consumed and where the social roles of the ancient nobility close to the sovereign are strengthened. The hegemony of the aristocratic group remains for a long time, at least until the $18^{\text {th }}$ century, however, a first bourgeoisie, that already appears between the fourteenth and sixteenth century, takes on new roles, activates and increases production processes, moves capital and investments, run credit and banks, so it becomes the subject of the modernization process (which, however, is not generalized but limited to some advanced geographical areas). Both the ancient nobility and this new bourgeoisie - imitating the first one - want to represent themselves also through their way of dressing, assigning to the dress an important symbolic function that allowed to follow the phases through which, starting from the custom, we arrive to the real FASHION [5]. For the life of the court the "gala dressing" is imperative, required in official ceremonies, parties, social or cultural gatherings, each garment emphasizes the careful aesthetic research and at the same time affirms the social superiority expressed through clothing - not only rich, but refined and original which confirms the dominated role of the sovereign and his followers, reaffirming the supremacy of the dynasties and privileged classes. But even the emerging and/or those already gradually emerged, which have gained a strong economic consistency, press to enter the political struggle marking an important epochal transition that changes the social structure in an irreversible way. Therefore the analysis of clothing in each era becomes another way of identifying the types of protagonists that move on the stage, the aristocracy of ancient origin, the later nobility, the many rural and capitalist bourgeoisies that transform their way of living - and dressing - into the expression of their power. This bourgeoisie is destined to emerge because it has the means of production (and distribution) and therefore over time assumes the control of the industries and the markets.

\section{Way to Produce and Social Classes}

In the long and complex process of change of European societies and economies, an important step is represented by the production of fabrics that has given rise to high quality factories and artistic handicrafts. Italy is among the first countries in the world to build an image of itself outside its own borders, with the experience of the Renaissance that marks a profound change, the result of a first productive, mercantile and banking bourgeoisie able to activate exchanges and consumption, artists and architects, commissions and patronage [6]. The vitality of the time, widespread in every field, explodes especially in factories, with the production of fine fabrics that prevail thanks to the quality of the raw material (wool or silk), the processing techniques, the variety of types, the attention to design and color, goods that acquire a surplus value because they are produced in the Italian peninsula, 
synonymous with taste and style that, in fact, is already a brand. The processing of cloths is an important advance in the development of production, becoming "industrial" during the transition between the Middle Ages and the modern age thanks to the introduction of new "machines" (mechanical looms) in the production process [7]. Wool and silk fabrics become points of excellence for many cities in northern Italy and northern Europe where one can find the origins of this first capitalism (protocapitalism), from where in the following centuries the real industrial revolution will start. The decorative motifs of the fabrics change over time but they are mostly inspired by nature, with "leaves, flowers, fruits, palms, grotesques, fantastic animals" [8]. A garment, a cloak, a ramage on a fabric, a veil on a hairstyle tell the individual and family history of the ruling classes, but they are part of a conceptual model, they express the ideology of an era and express it better and more than other documents thanks to the multiplicity of signs and symbols, of the dominant ethical and aesthetic canons. In the Sixteenth century, England, Flanders, the regions and cities of northern Italy - Venice, Genoa, Florence - proposed factories that became the driving sector of the economy and that remain in the historical memory as places of excellence for their quality products. Both weaving and dyeing testify to the importance of the processing phases and confirm the technical progress and the inclusion of the new raw materials used in the art of dyeing with colors related to the dictates of fashion. It is a great season that of the Renaissance, an explosion of vitality that involves politics, economy, art, architecture, food [9] and clothes, a strong theoretical model that draws the exemplary profile of the Italian peninsula, able to propose new "representations", in the articulation of ideas, in the design of the new urban morphology, in the elaboration of works of art, in the way of life. In addition to personal taste, the choice of clothes is conditioned also by the various treaties that are gradually published in which the authors discuss "about dressing in the latest fashion" giving rise to the formation of a corpus founded on the first rules. The Fashion dictates lines of trend, colors, measures, in tune with the ideological apparatus of the centuries set on different peculiarities: the symmetry and harmony of the Renaissance, the baroque sign of the seventeenth century, the rational and secular element of the eighteenth century, the bourgeois respectability of the nineteenth century, the avant-gardes (modernism, secessions) of the twentieth century. They are the prevailing characters that emerge from time to time and that for a long time - despite the social mobility and the pressure of the emerging classes have as background the courts of sovereigns in which every choice of clothing is aimed at appearing, distinguishing, excelling. Complex societies, however, contain contradictions, therefore, in parallel, it is also possible to record opposing tendencies, as it happens in the $16^{\text {th }}$ century which on the one hand favors the explosion of color, the beauty of the design, the fineness of the fabric, the harmony of proportions, but on the other hand it includes more rigid typologies responding to the aesthetic and moral rigor deriving from Protestantism, the absolute black interrupted only by the large white collars which affirms the severity of customs imposed by the religious principles of reformed Catholics and Catholics of the Counter-Reformation. Later, and in opposition, the Baroque age chooses redundant decorations and showy shapes, in architecture as in art, and applies to the dress the same distinctive traits, not without excesses, welcoming swollen and round lines that widen the figure, both feminine than masculine, sometimes encroaching on bad taste.

In short, preferring a fabric or choosing a dress is part of the ideological and psychological dimension, it refers every time to new perceptions of changing societies, becoming a rather "political" language registered by the descriptions of the sources. Notarial deeds, wills, matrimonial chapters, dowries describe analytically the clothing chosen on various occasions and allow to clearly outline the class differences and the differences deriving from local habits. It is a wide sector that shows the modalities of daily life and the rituals of institutional occasions, where the usual moderation of everyday life replaces the richness of clothes aimed at self-representation. Clothing for festive days and for institutional ceremonies, simple clothes to wear every day, garments and accessories for all occasions: cloaks and mantles, surcoats with various weight and color - like the cioppa, winter garment and the giornea, more light and youthful - tunics (cotte) for the most important occasions, shirts, bags, gloves, a rich wardrobe for the upper classes that need it in the social life in order to exhibit an additional value to their status.

The increase in the types and qualities of the clothes corresponds to the growth of the professional skills of the workers gathered in the Corporations - subdivided between major and minor Arts - weavers, dyers, wool and silk workers, tailors, hat producers, embroiderers, a large number of artisans with many skills. In addition to the type of the chosen fabric, for the dress system, for its architectural proportions, the color plays great importance and assumes different meanings, speaks its own language, communicates messages and refers to remote meanings, superstitions, ancient beliefs, reference models, symbolic contents that can only be understood by looking at communication codes and cultural canons, changeable in time and space [10]. Every era - and every country - shows its preferences based on factors that are not always easy to understand but which still include tastes, economic solidity and political trends. There are "classy" colors because they are more expensive - like the blue obtained from a mineral, the precious lapis lazuli, or the red obtained from the cochineal coming from the Americas - and there are moderate colors that express the severity and rigor imposed by religious conventions. When the Spanish influence fades in Europe, the penitential black of Philip II, king of Spain (1527-1598) also vanish, and the new fashion trend 
inspired by France proposes so much color, both pale and bright tones. Black remains a sign of mourning that expresses the pain of individuals and the participation of the community, but there is an explosion of yellow, red, blue, warm colors that represent joy and wealth. The aesthetic taste is evident in the marvelous period of Flemish and Italian painting which, through clothes, interprets the composition of society and marks class membership in a significant way. Among all, Agnolo Bronzino (1503-1572), the "portraitist" of the Medici court, adds to the representation of the subject every detail of the dress that allows analyzing processed and colored fabrics, often embellished with gold threads woven together with wool or silk, decorations of all kinds on damasks, brocades, velvets that embellish the texture with the design of floral motifs, fruits, feathers. Each element has the task of emphasizing the importance of the historical figure depicted and the clothes, together with the jewels and the accessories, play a central role in their minute description highlighting not only the social belonging but also the expressive and "emotional" dimension. The variety of images confirms the large number of fabrics that both production and commercial distribution - following the "first revolution" in the way of producing - make available on the markets, their shapes and their characteristics go hand in hand with the events that change the history of Europe, they mark divisions, modulate periodizations, highlight the events through which the different transitions are realized. The religious struggles, the scientific revolution of Galileo, the social revolts, the English industrial revolution are important events that mark dividing lines and indicate the new political, ethical, aesthetic categories. The dress, each time, can only follow the renewed tendencies and register the change in its real and symbolic semblance. The French Revolution represents an indicative example and emphasizes how the way of dressing shows very clearly its political and representative value. Once canceled the monarchy and the society of the Ancien Régime and proclaimed the Republic with the Declaration of the rights of man and of the citizen (central keystone of the democratic constitutions), the principles of liberté, egualité, fraternité are affirmed. The change that has taken place is immediately observable even in post-revolutionary fashion. Clothing becomes more sober, cancels redundant ornaments, eliminates excessive decorations and is inspired by the English model, also as adherence of the Jacobins to the democratic ideas of England, while the Girondins continue to comply with the aesthetic canons of their monarchy even if at that point it is an ended experience. The white, the red, the blue of revolutionary France dominate the fabrics, the clothes, the few decorations left (the cockades that became mandatory in 1792). The sans-culottes choose a "simplified" clothing that does not adopt the silk knee-breeches of the old nobility. The counterrevolutionaries, instead, according to their ideas, wear red ribbons around the neck that symbolizes the guillotine, black-lined clothes and shoes as a sign of mourning, white gloves in memory of the victims, in their opinion pure and innocent. Many nobles who flee the country seek refuge in London where they begin to assume the English lifestyle model including the way of dressing, starting if not the decline of French fashion, certainly its monopoly since the British style "enters" afterward gradually and it is destined to spread. The nineteenth century, the century of the idea of nation and nationalism, of the bourgeoisie, of liberalism, of capitalist development, combines the line of a profile that is linked to the different regional and local realities. Political-cultural history and economic-social history suggest complex paths where to place elites and emerging classes, new protagonists of a changing world. New figures move on the background of the Twentieth century, called "the short century" [11], which includes events designed to change the structure of the European and extra-European balances: the fall of the great Empires, colonialism, the First and the Second World War, the economic growth, the fall of the Berlin Wall in 1989. Once again the most significant transformations are connected to a change of direction not only in politics and economy, but also in the cultural mechanisms where fashion is an integral part.

\section{Fashion and Gender}

If in the $19^{\text {th }}$ century the society is still based on the subordination of women to men and the privileged position of the latter dominates [12], the symptoms of a first modernization are recorded at the beginning of the Twentieth century, when after the achievements (Déclaration des droits de la femme et de la citoyenne, the conquest of the right to vote, women's freedom) women want now to vote, to teach, to exercise the same professions of men. The First World War sends all the valid males to fight and the women are entrusted with their tasks, so they enter the factories allowing the continuation of the production processes [13]. It is a clear advancement and it is from that moment that we really come to the elaboration of the concept of gender diversity as a value that the societies governed by men up to that moment had not yet realized. In the long journey of demands, every step of the feminist movement corresponds to a similar modification of the way of thinking, of living, of dressing both for practical needs and for the affirmation in every way of a new freedom of women, in schools and shops, in the capacity to guide a car or even an airplane, the dress must now allow agile and fast movements, it can not be heavy or hinder the movements. The "new" women enter the production processes, they are interested in social problems, they deal with politics, they inaugurate a new dressing style by choosing garments with simple lines such as tailleur, knitted jackets, sweaters designed also for sports activities, casual clothing that shortens the skirts, uses more fresh and 
light materials, it is still divided between high and working classes but somehow makes the distance seem shorter because the transition from rural civilization to urbanization has also changed the dynamics of work and the division of labor between the sexes has uniformed functions and items of clothing both for work garments and more generally for the new ways of life.

\section{Paper Clothes. Celebrations, Game, Cultural Models}

The interdisciplinary approach, which has allowed us to broaden the field of research and analyze the material conditions of the existence, has also allowed us to operate continuous contaminations between "high" and "low" culture, leading to new suggestions. If the trends of the different historical moments have emerged from the Fashion observatory, perhaps it is possible to apply the same theoretical model by using it in other areas, in my opinion not without significance, capable of proposing some unusual theme. From here the idea of continuing the investigation looking at the clothes of the characters represented on the playing cards that can explain significant "fragments" of the many histories of the European civilization. The game, considered by cultural anthropology in its various meanings and especially as a phenomenon observed for the social sciences [14], must be included in the broader context of the celebration, which is filled with a different content depending on social belonging. It must be said that, in a general sense, the concern of the political and religious authorities expressing disapproval of the different kind of games is considered as a possible cause of deviant behavior that does not conform to morality. It is easy, in fact, that it leads to excesses becoming a problem for public order - for example, when somebody loses money (without even having the money) the temptation to help the adverse fortune by cheating is strong - and causes even serious quarrels which can become violent actions. Consequently, both religious rules and a specific legal regulation try to place limitations recalling ethical principles and laws that however can not stop the rapid spread of the phenomenon because for ordinary people the stop of activities on holidays is a precious occasion in addition to the obligatory rest on Sunday and therefore it must include a pleasurable type of entertainment which is not to given up in any way. The circumstances are different if the celebration (and the game that it contains) takes place in the city or in the country side, if the dominant classes or the lower classes are involved, if it concerns males or females, young people or adults. The articulation is wide, the social groups differentiated, there are the ancient nobility and the country aristocracy, the close entourage of the nobles of the court, the urban elites consolidated in business or starting to work within the city magistracies and the bureaucracy of the
State, a "divided" society based on origins, roles, economic consistency, political weight [15]. And if for administrators the goal of the celebration is social and political and playing games must never fail even at the cost of blowing up the budgets of central and local authorities, the fact remains that for the people those are liberating moments when people has the possibility of venting their dissatisfactions by accepting, in some cases, to simulate the cancellation of social hierarchies between subordinate and dominant classes with ceremonies - like a crowded procession or a cheerful masked ball - in which different classes can participate, creating a sort of "circularidad" [16] between nobles and plebeians that brings together ordinary and influential people. More commonly, however, in the interruption of the daily pattern, each category is organized differently, the nobles spend much of their time in physical exercise as a preparation for a military carrier, they go hunting and take part in medieval style tournaments, but they also participate in social events (often very expensive), such as balls, literary salons, theatrical performances, banquets, while the popular celebration offers street shows, greasy poles, a break in the tavern. A crucial moment during the festive days is the game, which contains cultural, ethical, psychological and economic dimensions. If the game of chess is mainly present among the higher classes, the card game is transversal, it concerns both masters and insignificant people, it articulates the time of the party but also enters daily life, it spreads in every environment, plays a consolatory role, creates an emotional tension that everyone likes becoming therefore an important social shock absorber. But, regardless of the complex events characterizing the history of the game, we have chosen here to follow the path of the clothes depicted on the playing cards that help us identify the salient characters of the societies they represent. The most ancient cards appear in Lombardy on the occasion of the wedding of Filippo Maria Visconti who offers them to his wife Beatrice Lascaris Ventimiglia (1412). These cards - famous in history with the name of the Visconti tarot - are a precious gift and are produced by a famous painter who follows the same technical procedure used for the miniatures by adding magnificent decorations to describe the chosen allegorical subjects. The images represent the medieval society and are inspired by heraldry, astrology, mythology, thus proposing knights and knaves, armors, shields, swords, banners with the insignia of the dynasties, confirming the military setting of the tarots and of the subsequent playing cards, even if diversified in the different European countries with regard to the choice of the subjects and the technical craftsmanship. The clothing of the various selected characters helps to delineate their function and importance and emphasizes the signs of the religious and secular/political power by underlining the preciousness of the clothes, the splendor of the colors, the force of the depicted subjects, at the top of the sacred imagery and profane power: Emperor and Empress wear sumptuous 
gold dresses lined with blue velvet - blue and gold express wisdom - the scepter, the crown, the shields are the sign of power and even the dress of the Pope is a golden surcoat lined with green to which is added the triple crown (triregnum) with the insignia of the Holy Roman Empire. The Papessa, instead, who holds a cross and wears a humble monastic dress, represents the feminine, spiritual side, in opposition to the masculine, material side. Both refer generally to the tripartition body, soul, spirit. The Moon and the Stars recall the celestial vault and are presented as young women richly dressed, the first wearing a blue dress with pink and gold overcoat, the second a blue dress and a two-colored mantle embroidered in gold. The Lovers are two young people wearing court dresses, the woman with a dress embroidered in gold, the man with a short blue, golden coat. The Hermit is an old man dressed in blue holding an hourglass as a metaphor of the time passing and leading to death. The clothes depicted in these cards, as in other cards, and worn by the characters and the colors chosen by the artists who painted them express the spiritual and secular life and present a review of subjects that refer to the composition of the society, still divided into classes - warriors, churchmen, workers, merchants - a series of figures in which the dress is an integral part of a language entrusted to the images and the symbolism that they contain. Similarly, in the French cards called of "Charles VI" (1368-1422), we find the representation of court life in which hierarchical subordination and social diversity persist. Many figures are similar to those of the tarots, others add their own elements of the history of France, with ladies and queens wearing extraordinary toilettes made of fine fabrics often fur lined [17]. Later, over time, the illustrations on the cards, while retaining some reference to the past, introduce new subjects and new symbols - national and local - adapting to the transformations of the societies that gradually contribute to describing even through those "paper clothes" that testify the change of the political thought and the aesthetic canons, at least until the French Revolution, when, as we have seen, more than ever, the symbolism of clothes will become evident.

\section{Porcelain, Mon Amour}

If the manufacture of ceramic - lacquered, painted, glazed, scratched - accompanies the history of each country and region of Europe, we must wait for the $18^{\text {th }}$ century to have the porcelain, until then imported from the East. The passion of the European sovereigns and of the Ottoman sultans feeds an important commercial traffic that connects the production areas (China, Korea, Japan) to the ports of the Old Continent, thanks to the link between Lisbon and Macao - considered since the mid-sixteenth century (1557) a Portuguese overseas province - and also thanks to the East India Company, a group of companies from different
European countries (England, Holland, France, Denmark, Sweden) that between the Seventeenth and Eighteenth centuries have a monopoly of trade with the East and West Indies. The porcelains arrive first along the silk road, like spices and lacquer, then, after the first voyage of Vasco de Gama which opens a sea route to the Far East (1497-1499), it is preferred to send them by sea. Passion changes into obsession, possessing porcelain, in Europe, becomes one of the many connotations of power, it is a goal that only few can reach by buying from the eastern countries. Augustus II Wettin (1670-1733), known as the Strong, Elector of Saxony and King of Poland, spends huge sums for the exclusivity of the porcelains that came from Canton to Amsterdam and from there redistributed throughout the continent. The eighteenth-century world is fascinated by the esoteric research, wants to reach a wider knowledge, seeks at the same time the "recipe" of immortality and the advancement of science, princes and sovereigns, while procuring precious porcelain objects, support scholars and alchemists in the attempt to find the philosopher's stone. This ambition of the Saxon sovereign to reach the goal is so strong that he keeps as prisoner in one of his castles the alchemist Böttger, who is in charge of finding the magic formula. When, during his research, he discovers the secret of porcelain and finds the formula of "hard clay" thanks to the identification of the main ingredient, the kaolin, the event is so important that the invention is announced to the world in four languages, Latin, French, German, Dutch. While the Elector proposes Dresden as a new cultural capital, "luxurious and elegant [18], the factory is located in the Gothic castle of Albrechtsburg, not far from the court. The production immediately becomes a cult, the factory creates "pieces" of great beauty that satisfies the taste of the most demanding consumers and spreads rapidly, perhaps even favored by the bourgeois - secular - clientele that in fact replaces the commissions of the Church, especially in countries where the Protestant Reformation has been affirmed. Consequently they produce precious dining sets, decorated and masterfully painted with many colors, created by talented artists, intended to beautify the tables of the powerful during the most important official occasions. The intense activity of a large number of artists offers a multitude of decorative compositions that combine leaves, fruits, bouquets, landscapes, geometric designs in cobalt blue, coral red, verdigris, yellow, the upper classes can no longer ignore them when they want to honor a guest, to make a good impression, to stand out from the others, court dignitaries, the not yet impoverished nobility, emerging classes that gradually enter the top of society, all aspire to those new products, an extreme sign of distinction. The production, therefore, has been a great success and soon, from refined dining sets, they manufacture porcelain figurines, used not only as furnishing compendiums, but also as table centerpieces to replace the sugar "triumphs" that had enriched the tables of the aristocracy especially on special occasions such as weddings or royal visits during 
the previous centuries. The possibility of building not a flat image, but a complete figure emphasizes its value, specifies its uniqueness, and adds to the reproduction the "roundness" of the three dimensions capable of enriching and clarifying characters and roles of the subjects by creating a dynamic dimension. The choice of the subject, the pose, the overall framing combine in order to create a complex reality, a "whole" formed by the central interpreter often accompanied by small animals, children and servants, which no longer testifies the individual, but an entire social category - the bourgeoisie - represented in its daily life or during celebrations. These protagonists are different and define themselves also and above all thanks to the clothes they wear, skillfully painted clothes that bring out the richness of the fabrics, the colors, the decorations, the "accessories", in short the signs of class belonging. The style of the statuettes is due to the Eighteenth century concept that combines rationalism and secularism but is also dictated by the choices of the model master that imprints its sign undeniably and, indeed, with Kandler (1731-1774) the trend is fully baroque, with very adorned and colored clothes that express at best the "feeling" of redundant decorativism, symbol of the joy of court life (and of the celebrations), while with Marcolini (1774-1813) the neoclassical prevails and, as a predominant trait, chooses simplified and "clean" lines. In both cases, the porcelain artists present ladies and knights, family groups, but there are plenty of peasants, street vendors, commoners, young people in traditional costumes, a gallery of characters that express the society of the time depicted on the background of a bourgeois drawing room, a market, a pastoral scenery, a multiplicity of forms communicating reality and social differences. Like this, masterpieces of incomparable beauty are created, single figures, couples, groups, composed at that time and repeated in the following years by the company with "copies" (multipli) that still succeed nowadays to transmit emotions involving collectors and admirers (as it happens at Sotheby's auctions). The setting of the genre scenes describes the ruling élites portrayed in their boudoir, the artists, modelers, sculptors, painters, propose ladies with bright and luxurious clothes - adorned with floral and embroidered rouches, often also exaggerated - elegant and refined men in various declinations, family groups where also the clothes of the children are appreciated and very similar to those of the adults (for a specific children's fashion we must wait for the Nineteenth century), an entire world realized in the splendor of the translucent porcelain that accentuates the beauty of the clothes considered fashionable in that moment. As in an art gallery, we can appreciate: a lady with a ramages skirt that opens under a yellow coat, with a fan in her hand and a dog on her lap (symbol of loyalty); a knight with a bright red redingote with a tricorne in his hand; another lady wearing a flowered dress with a wide skirt; a group portrayed in a gallant scene animated by figures in colorful clothes; la bonne mère, a lady with a high eighteenth-century wig, surrounded by her three sons; a lady with a wide dress finished in gold. Other statues depict popular figures, small street vendors, women wearing an apron on colored skirts, countrywomen bringing their products to sell at the market with baskets full of flowers and fruits [19].

\section{Conclusions}

FASHION, as we have considered it, is an integral part of the history of peoples because every era inscribes its sign in the ideological model of reference whose constituent elements are reflected on the way of dressing. The dress is one of the elements that allows to decline the different types of subjects that move on the scene of power, nobles of ancient origins or emerging classes who, through the clothes and accessories that surround them, intend to define their own image according to certain, even aesthetic canons. From the Middle Ages to the Eighteenth century specific prohibitions, sumptuary laws are concerned with fighting the propensity to luxury towards which the dominant classes tend to exceed because of the richness of clothing adopted to distinguish themselves, to emerge, to excel. In spite of such normative devices, however, the tendency of social groups to choose a sumptuous and sought-after clothing remains, particularly on special occasions such as weddings, parties, celebrations of various kinds, the ancient nobility by tradition, the emerging classes to assert their social climb and get recognition compared to the first ones. In fact, neither the Church nor the administrative authorities manage to curb the ambitions of the ruling classes, one for moral reasons, the other in order to limit the excessive showing of clothes, colors, additional signs of power, intended to mark the differences of class.

However, societies that over time are changing in power relations are projected towards forms of freedom, politics and aesthetics, which inevitably also influence the way to dress, especially when two major epochal events leave their mark - the industrial revolution in England and the French Revolution - including economic-productive and political-social life, changing the face of European society, affirming the value of reason and of direct experience.

The indicated path, which privileges the interpretation and analysis of the many values of fashion, narrates, describes, deepens main characters and details not completely irrelevant proposing some unusual deviation where the research is addressing, in addition to the usual sources, to "specialized" Italian, French, Spanish, and especially Saxons archives - such as Staatliche Porzellan-Manufaktur and Sächsisches Hauptstaats Archiv Dresden - and to other material documentation that allowed us to perceive the importance of clothing beyond the usual testimonies. The incursions into the dress of the miniaturists who paint the tarot cards and that of the model 
masters who decide the style of Meissen figurines have unveiled an entire world, parallel lives - powerful sovereigns, shining nobility, bourgeois, modest workers evoked to represent a society divided into classes that nevertheless the preciousness of the images makes equally exclusive, a sign, a cultural index that has allowed us to leaf through the pages of History in a new way. In fashion, each passage is linked to the broader context of the ideas and culture of each era, alternating continuously tradition and innovation, reflecting the change of societies seen in their diachronic development where the dress has perhaps a more important meaning than it may appear at first sight.

\section{REFERENCES}

[1] Burke P., La storiografia contemporanea, Roma-Bari: Laterza; 2000; Tosh J., Introduzione alla ricerca storica, Firenze: Nuova Italia; 1989.

[2] Braudel F., Civilisation matérielle, économie et capitalisme, $X V^{e}-X V I I I^{e}$ siècle 1 . Les Structures du quotidien - 2. Les Jeux de l'échange - 3. Le Temps du monde, Paris, Armand Colin; 1979.

[3] Motta G., Nell'Europa dell'Età Moderna,. Memoria collettiva e ricerca storica, Firenze: Passigli; 2013

[4] Bauman Z., Postmodern Ethics, Oxford, Cambridge (Massachusetts) 1993; id., Culture in a Liquid Modern World, Cambridge 2011; id., Futuro liquido. Società, uomo, politica e filosofia, Milano: AlboVersorio; 2014

[5] Levi Pisetzky R., Il gusto barocco nel costume italiano del Settecento, in Studi seicenteschi, II, 1961; id. Il costume e la moda nella società italiana, Torino: Einaudi; 1978; Sombart W., Lusso e capitalismo, Parma: Edizioni all'insegna del Veltro; 1982; Simmel G., La moda, Milano: Mondadori; 1998; Lipovetsky G. - Roux E., Le luxe éternel. De l’âge du sacré au temps des marques, Paris: Gallimard; 2003; Barthes R., Il senso della moda. Forme e significati dell'abbigliamento, Torino: Einaudi; 2006; Marchetti M.C., La moda oltre le mode, Roma: Nuova cultura; 2011; Carteny A., Introduction in G. Motta, Fashion becomes History, Rome: Nuova cultura; 2018

[6] Motta G., La moda si fa storia. Di nobili e d'eroi, di borghesi e rivoluzionari, abiti, ruoli e identità nazionali, Firenze: Passigli; 2016

[7] Melis F., Documenti per la storia economica dei secoli XIII-XVI, Firenze: Olschki; 1972; Id. Gli opifici lanieri toscani nei secoli XIII-XVI, in Produzione e consumo dei panni di lana, Firenze: Lemonnier; 1974

[8] Motta G., Il mercante di panni, Firenze: Passigli; 2009

[9] Motta G., Food and Culture. History, Society, Communication, Roma: Nuova Cultura; 2017

[10] Pastoureau M., I colori del nostro tempo, Firenze: Ponte alle Grazie; 2010;

[11] Hobsbawm E., Age of extremes: the short twentieth century, 1914-1991, London: Abacus; 1995

[12] Duby G. - Perrot M., Storia delle donne in Occidente, Roma-Bari: Laterza; 1991; Zemmon Davis N., Donne ai margini. Tre vite del XVII secolo, Bari: Laterza; 1996; Motta G., Regine e sovrane. Il potere, la politica, la vita privata, Milano: Franco Angeli; 2002, Archivi di famiglia e storia di genere, Roma: Nuova Cultura 2010; La città delle donne. Storie metropolitane al femminile, Firenze: Passigli; 2012; La storia e il genere. Donne in un mondo di uomini, in Nell'Europa dell'Età Moderna cit.

[13] Biagini A.- Motta G., The First World War. Analysis and Interpretation, Newcastel: Cambridge Scholars; 2015; Pommier Vincelli D., The Changellenes of Postcolonial Nation, in Empires and Nations from the Eighteenth to the Twentieth Century, New Castel: Cambridge Scholars; 2014

[14] Huizinga J., Homo ludens, Torino: Einaudi; 1973;

[15] Janssens P., Les loisirs aristocratiques dans l'Europe prè-industrielle, in Il tempo libero. Economia e società, Firenze: Le Monnier 1995

[16] García Martín P., A. Mora Cañada, Las fiestas populares en España, Siglos XVI-XVIII, in Il tempo libero. Economia e società, Firenze: Le Monnier; 1995; Gonzalez Tornel P., Roma hispanica. Cultura festiva española en la capital del Barroco, Madrid: Centro de Estudios Europa Hispánica (CEEH); 2017

[17] Belmas E., Jouer autrefois. Essai sur le jeu dans la France moderne (XVIe-XVIIIe siècle), Seyssel: Champ Vallon; 2006. For the court life in Spain, cf. Colomer J.L.- Descalzo A., Vestir a la española en las cortes europeas (siglos XVI-XVIII), Madrid: Publicación: Madrid : Centro de Estudios Europa Hispánica, D.L. 2014;

[18] Gleeson J., L'alchimiste de Meissen. L'extraordinaire histoire de l'invention de la porcelaine en Europe, Paris: Lattès; 2001; Godden G.A., Oriental Export Market Porcelain and its Influence on Euripean Wares, Londra: Granada 1979; Meister P.W., Reber, European porcelain of the $18^{\text {th }}$ century, Oxord: Phaidon; 1983 ;

[19] Motta G., Suits of Cards, Statuettes and Fairy Tales, in Fashion through History: Costumes, Symbols, Communication, New Castle: Cambridge Scholars; 2017 